\title{
Real Exchange Rate Misalignment in Jordan: The Permanent Equilibrium Approach
}

\author{
Noura Abu Asab ${ }^{1}$ \\ ${ }^{1}$ Department of Economics, School of Business, University of Jordan, Amman, Jordan \\ Correspondence: Noura Abu Asab, Department of Economics, School of Business, University of Jordan, P.O Box \\ 11942, Amman, Jordan. E-mail: n.abuasab@ju.edu.jo
}

Received: December 23, 2016

Accepted: January 11, $2017 \quad$ Online Published: February 15, 2017

doi:10.5539/ijef.v9n3p29

URL: http://dx.doi.org/10.5539/ijef.v9n3p29

\begin{abstract}
This study attempts to measure the real exchange rate misalignment in Jordan from 1980 to 2014. We examine the role of adopting the pegged exchange rate system to the US in 1995 in limiting/increasing misalignment. Applying the Johansen approach, a cointegrating relationship is found between the real exchange rate and a number of economic fundamentals that influence the long-run real exchange rate. Over a long examined period of exchange rate fixity, the real exchange rate is kept depreciated except after 2006-2008 over which the appreciation of the real exchange rate is noted. However, after 2011 misalignment receded as the real exchange rate matched the equilibrium real exchange rate. An attempt is also made to model the nexus between the growth of per capita income and misalignment. The exchange rate misalignment is found to significantly decrease the economic growth.
\end{abstract}

Keywords: real exchange rate, misalignment, cointegration, fixed exchange rate

\section{Introduction}

Real Exchange rate misalignment has been one of the most important topics in international macroeconomics. Real exchange rate may deviate from its parity or long-run equilibrium due to Changes in economic fundamentals (Rogoff, 1996). When real exchange rates diverge from this equilibrium, a country's currency is said to be misaligned. This might be associated with fiscal or monetary policy which affects the external and internal balance (Marston, 1988). This means that real exchange rate is the outcome of the economy's macroeconomic equilibrium and, consequently, deviations from the long-run equilibrium can be attributed to economic policies (Kubota, 2009). Therefore, the nominal exchange rate regime followed by the monetary authority can play an important role in inducing less or more misalignment volatility.

It is believed the choice of nominal exchange rate regime affects the real exchange rate misalignment (Holtemöller \& Mallick, 2008); (Coudert \& Couharde, 2009); (Dubas, 2009). Misalignment is found to be less risky in countries with floating exchange rates compared to fixed exchange rate targeters since the floating regime allows the foreign exchange rate market to adjust to determine the optimal real exchange rate (Dubas, 2009). So, the higher the fixity of exchange rate regime the higher the exchange rate misalignment. Fixed exchange rate systems can maintain non-trivial misalignment for a long period of time due to massive central bank interventions and the stickiness of prices especially in less efficient goods markets as in the case of developing countries (Nouira \& Sekkat, 2015) (Note 1).

Examining real exchange rate misalignment is highly important for policy-making when the nominal exchange rate is targeted. This is because a change in the relative prices of the base country's goods and the following country's goods misaligns the real exchange rate from its long-run equilibrium level, stated by domestic macroeconomic fundamentals. The persistent deviation from the long-run equilibrium has effects on a variety of economic variables such as economic growth, currency crisis, foreign direct investment and capital accumulation (Nouira \& Sekkat, 2015). Thus, measures of misalignment are used for prediction of future depreciation and evaluation of the links between exchange rates and economic performance. In addition, when exchange rate is fixed by government, it is essential to assess the need for devaluation or revaluation of exchange rate parity. It is pointed out that most emerging market economies induce devaluation to keep their exports competitive, and so real exchange rate is often used as policy tool to facilitate economic growth (Rodrik, 2008); (Aizenman \& Lee, 2007); (Hausmann et al., 2005). 
In this paper we attempt to measure the real exchange rate misalignment in Jordan to assess the role that the fixed exchange rate to the US dollar has on misalignment. Given this, the real exchange rate, computed as the nominal exchange rate in domestic terms adjusted for the relative prices of the US and domestic prices, is used instead of the real effective exchange rate, which is the most commonly used in the literature as the observed real exchange rate.

To our knowledge, only two studies have been written on real exchange rate misalignment in Jordan. The first study by Petri and Saadi-Sedik (2006) assess the impact of grants and workers' remittances on real effective exchange rate over the annual period from 1964 to 2005. Using cointegration technique and applying the Hodrick-Prescott and Band-Pass filters, they identify the equilibrium real effective exchange rate based on some macroeconomic fundamentals, i.e. terms of trade, openness and fiscal balance. The results show that grants and remittances appreciated the exchange rate over the examined period. The second study is done by Warrad who measures the real exchange rate misalignment over the fixed exchange rate to the US dollar period, i.e. 1996 to 2012 using quarterly data, and examines the effect of misalignment on economic growth represented by real GDP. The methodology to estimate the equilibrium real exchange rate is apparently the purchasing power parity, which presumes stationary of fundamentals and a priori specified base year, the method which is widely criticized of its limitations. However, the paper fails to show how the fundamentals are considered and how the measure of misalignment is calculated. Contrary to both studies, this paper aims to examine the impact of adopting the fixed exchange rate to the US dollar upon the real exchange rate misalignment, so we apply the permanent equilibrium exchange rate approach to the years before and during the fixed exchange rate system to the US dollar, adopted in October 1995 (Note 2). The integrated estimates and the long-run values of the fundamentals are used to compute the equilibrium real exchange rate, and consequently to calculate the exchange rate misalignment. It is found that the real exchange rate is kept misaligned and depreciated for a long period of time during the exchange rate fixity years under examination. The misalignment measure is also incorporated to examine the impact on economic growth represented by growth in GDP per capita income. The results indicate that misalignment significantly reduces the economic growth.

The reminder of the paper is organized as follows. Section two presents the analytical framework. Section three and four provide data sources and estimation of the equilibrium real exchange rate and misalignment, respectively. Concluding remarks are presented in section five.

\section{The Analytical Framework}

Different theoretical approaches have been developed to set the unobserved equilibrium real exchange rate, and consequently, to measure the exchange rate misalignment of a currency. The first approach to measuring misalignment is established based on the purchasing power parity theory, which is widely used due to its simplicity. The relative purchasing power parity assumes stationary of fundamentals and the exchange rate is considered over-valuated or under-valuated if the nominal exchange rate deviates from the exchange rate suggested by the theory. The main problem with this methodology is that a specific year in which the real exchange rate was in equilibrium should be identified a priori (Hinkle \& Monteil, 1999). Furthermore, the fundamental determinants of the real exchange rate are assumed to be stationary over time, and so in case of a structural change in the fundamentals, the estimates are not meaningful.

The other approaches are classified under one category of the equilibrium based approaches, which take broader macroeconomic fundamentals into considerations (Kiptoo, 2009). Under these approaches, real exchange rate misalignment is calculated as the deviation of the actual real exchange rate from a theoretically-based equilibrium path of the real exchange rate (Hinkle \& Monteil, 1999); (Edwards, 1989); (Frenkel \& Razin, 1996). Baffes, Elbadawi, and O'connell (1997) adopt a single reduced form to determine the long-run exchange rate. It includes the fundamentals in a dynamic structure of the economy which is determined totally by the data. The fundamentals are cointegrated with real exchange rate and consist of domestic absorption, terms of trade, trade openness among other economic variables.

Most empirical studies on the exchange rate misalignment employ either the behavioral equilibrium exchange rate or the permanent equilibrium exchange rate. Although the two approaches consider different macroeconomic conditions of the real exchange rate, the former model focuses on the short-run dynamics behavior of the exchange rate, see Clark and MacDonald (1997), whereas the emphasis of the later is on the long-run movements in the real exchange rate. This long-run real exchange rate is different from the desired long-run real exchange rate, where the latter depends on optimal values of the policy variables, permanent values of the exogenous values and the steady-state values of the predetermined variables (Hinkle \& Monteil, 1999) (Note 3).

This paper employs the permanent equilibrium exchange rate approach and projects some macroeconomic 
fundamentals that may explain the behavior of real exchange rate in Jordan, given the macroeconomic conditions of the economy. This equilibrium based approach captures the long-run movements in real exchange rate, where the permanent long-run values of the fundamentals are decomposed by the Hodrick-Prescott filter and substituted into the proposed stationary relationship between the real exchange rate and some relevant macroeconomic determinants.

The macroeconomic fundamentals considered in the literature usually involve government spending, terms of trade, capital and aid flows, foreign assets, factors related to monetary policy, among other fundamental variables. Given the limited availability of data for Jordan and short time-series at hand, this study projects net foreign assets, government expenditure, money supply growth over GDP growth and interest rate differential between the domestic economy and the US over the yearly span from 1980 to 2014.

The relationship between the real exchange rate and its fundamental is constructed as follows.

$$
r e r_{t}=\alpha_{1}+\alpha_{2} n f a_{t}+\alpha_{3} \exp _{t}+\alpha_{4} M S_{t}+\alpha_{5} I R D_{t}+v_{t}
$$

The left hand side of the equation is the real exchange rate to the US dollar, defined as the nominal exchange rate in domestic term adjusted for the prices of the base country and domestic prices. The domestic term of the nominal exchange rate indicates that a decrease (increase) in the value of the real exchange rate means appreciation (depreciation) of the real exchange rate. The lowercase letters refer that the variables are taken in natural $\log$ form, where nfa is the net foreign assets in LCU billion and exp is the government expenditure in LCU billion. MS is taken as an indicator for monetary policy stance in Jordan, and denotes the difference between the growth in broad money supply $\mathrm{M}_{2}$ and the growth in GDP. IRD is the nominal interest rate differential between the domestic interest rate, i.e. the rediscount rate and federal fund rate. $v_{t}$ is the white-noise error term.

We calculate the real exchange rate misalignment as the deviation of the actual value of the real exchange rate from its long-run equilibrium value; mathematically this can be shown as follows.

$$
M I S=R E R-E R E R
$$

Where RER is the actual real exchange rate. ERER is the multiplication of the long-run component of the fundamentals of the real exchange rate, decomposed by the Hodrick-Prescott filter, and the estimated coefficients of equation (1). When misalignment is negative, the actual exchange rate is said to be overvalued, while a positive sign indicates an undervaluation of the actual real exchange rate.

\subsection{Macroeconomic Determinants}

1) Net Foreign Assets: net foreign assets determinant is an indicator of the country's capacity to import. An increase in net foreign assets increases the demand for tradable and non-tradable goods which leads to real exchange rate appreciation (Elhendawy, 2012). So, the sign of $\alpha_{2}$ is expected to be negative.

2) Government Expenditure: it is supposed that the expansion of the government expenditure will increase the demand for on-tradable to tradable goods. This demand increases the prices of non-tradable goods which, consequently, results in real exchange rate appreciation. In other words, domestic borrowing increases with the expansion of government expenditure. The level of domestic interest rate will increase appreciating the real exchange rate (Kiptoo, 2009). However, data on government consumption on non-tradable goods is often non-available for any country and so this fundamental is usually replaced by the government consumption. Hence, the sign of $\alpha_{3}$ cannot be expected a priori.

3) Monetary Stance: to assess the overall stance of the domestic monetary policy, the MS is included as a determinant of domestic demand. Although the growth of money supply is supposed to be restricted to increasing for exchange rate fixers, a looser monetary policy may be conducted by soft-peggers like Jordan. Therefore, the expected sign of $\alpha_{4}$ is negative.

4) Interest rate differential: a positive interest rate differential is assumed to induce capital inflows to the domestic country leading to real exchange rate appreciation. Hence, the sign of $\alpha_{5}$ is expected to be negative (Note 4).

\section{Data Sources}

Yearly data on real exchange rate fundamentals from 1980 to 2014 are imported from different sources. Gross domestic product and net foreign assets are collected from the world development indicators database. Data on Jordan's rediscount interest rate and broad money supply are extracted from the central bank of Jordan statistical database, while data on Jordan's government expenditure are collected from different releases of the central bank reports. The United States federal fund rate are imported from the database of the Federal Reserve. 
To calculate the real exchange rate, we import yearly data from 1980 to 2014 on consumer price index for Jordan, and nominal exchange rate to the US dollar from the central bank of Jordan statistical database, while the consumer price index for the United States is extracted from the IMF outlook database. Data on population and the ratio of investment to GDP are also imported from the IMF outlook database to modeling the relationship between misalignment and growth.

Table 1. Descriptive statistics

\begin{tabular}{ccccc}
\hline & LNFA & LGOVEXP & IRD & MS \\
\hline Mean & 21.39565 & 3.281540 & 1.270857 & 1.392821 \\
Median & 21.50057 & 3.275127 & 2.530000 & 0.513787 \\
Maximum & 23.00440 & 3.894931 & 5.480000 & 17.49647 \\
Minimum & 19.48440 & 2.731911 & -9.890000 & -11.25388 \\
Std. Dev. & 1.188365 & 0.352029 & 3.673181 & 6.494996 \\
Skewness & -0.205332 & 0.264327 & -1.347533 & 0.294576 \\
Kurtosis & 1.545741 & 1.913963 & 4.332890 & 2.821596 \\
Observations & 35 & 35 & 35 & 35 \\
\hline
\end{tabular}

\section{Estimation of the Equilibrium Real Exchange Rate}

\subsection{Unit Root and Cointegration Tests}

In the first step, we check for the presence of a unit root in the relevant variables series. The Augmented Dickey Fuller (ADF) (1979) and Philips-Perron (PP) (1988) tests are applied to test for the stationary of the variables considered in equation (1) and the optimal lag length of the test is determined by the Schwarz information criterion. The results in Table 1 show that all the variables except the monetary stance (MS) variable are stationary at first difference. This means that the variables may form a long-run relationship of the real exchange rate.

To specify the cointegrating rank of the system, we apply Johansen (1988) methodology. In contrast to Engle-Granger cointegration test, the estimation strategy of Johansen test allows estimating all cointegrating vectors at once, that is, when there is $n$ variables with unit roots, there is $n-1$ cointegrating vectors. The Johansen approach can be written mathematically in the vector autoregressive of order $\mathrm{j}$.

$$
y_{t}=\mu+\pi y_{t-1}+\sum_{i=1}^{j-1} \tau \Delta y_{t-1}+\varepsilon_{t}
$$

Where $y_{t}$ is an $\mathrm{nx} 1$ vector of variables that are cointegrated of order one, $\varepsilon_{t}$ is an nx 1 vector of shocks and subscript $t$ denotes time.

$$
\pi=\sum_{i=1}^{j} A_{i}-I \text { and } \tau=-\sum_{n=i+1}^{j} A_{n}
$$

When the coefficient matrix $\pi$ has a lower cointegrating rank, that is $\mathrm{r}<\mathrm{n}$, there is nxr matrices of $\alpha$ and $\beta$ each with rank $\mathrm{r}$, in which $\hat{\beta} y_{t}$ is stationary (Hjalmasson \& Osterholm, 2007). $\alpha$ is the speed of adjustment to disequilibrium and $\beta$ is the cointegrating vector.

Johansen suggests two maximized likelihood functions: the maximal eigenvalue and lambda max statistic tests.

$$
\begin{gathered}
J_{\text {trace }}=-T \sum_{i=r+1}^{n} \ln \left(1-\hat{\delta}_{i}\right) \\
J_{\text {max }}=-T \ln \left(1-\hat{\delta}_{r+1}\right)
\end{gathered}
$$

Where $T$ is the sample size and $\hat{\delta}_{i}$ is the $\mathrm{i}^{\text {th }}$ largest canonical correlation.

The null hypothesis of both tests is that $r$ cointegrating vectors do exist. The alternative hypothesis of the trace-test is that there is $\mathrm{r}+1$ cointegrating vector, whereas the alternative of the maximal eigenvalue test is the existence of $\mathrm{r}+1$ cointegrating vector.

We proceed to look for a cointegrating relationship relating the real exchange rate to the macroeconomic fundamentals. Given that most of the real exchange rate determinants chosen in the study are first-differenced stationary, as can be seen from Table 2, a linear relationship between the real exchange rate and the fundamental are presumed to exist. The general form of the relationship can be expressed as follows.

$$
r e r_{t}=\alpha_{0}+\beta_{t} K_{t}+v_{t}
$$

Where $r e r$ is the equilibrium real exchange rate. $\beta$ is a vector of long-run coefficients of the fundamentals. $v$ is the white-noise error term and subscript $t$ denotes time.

The maximal eigenvalue and lambda max statistic confirm the existence of a one co- integrating relationship. As 
it is clear from the results presented in Table 3, the two tests indicate the there is only one cointegrating relationship between the variables according the critical values of Osterwald-Lenum (1992) of model 3, where a constant and linear trend are imposed in the cointegrating space and data space, respectively. The estimated coefficients of equation (7) are all significant at 5\% level of confidence. According to both tests, the null-hypothesis of no cointegration, i.e. $r \leq 0$ is rejected while the null hypothesis that the order of integration is two, $r=2$, could not be accepted, confirming that only one cointegrating relationship exists among the considered variables.

Consequently, the estimation of the long-run model of the normalized cointegration is presented in Table 4. All the parameters of the macroeconomic fundamentals are highly significant and their sign is found to be consistent with the theory and the empirical literature and the estimated model is lack of autocorrelation and heteroskedasicity problems.

According to the results, the improvement (deterioration) in the foreign assets decreases/appreciate (increases/depreciate) the real exchange rate. Likewise, a one percent increase in the excess of money supply to the growth of GDP appreciates the real exchange rate by 12\%. A $10 \%$ increase in nominal interest rate differential between Jordan and its base country also appreciates the real exchange rate by around $3.1 \%$. By contrast, it is found that government consumption increases the real exchange rate by a large magnitude. A one percent expansion of government spending depreciates the real exchange rate by roughly $2.8 \%$ (Note 5 ).

Table 2. ADF \& PP unit root test

\begin{tabular}{ccccccccc}
\hline \multirow{2}{*}{ Time Series } & Level & Prob. & F-D & Prob. & Level & Prob. & F-D & Prob. \\
& ADF & ADF & ADF & ADF & PP & PP & PP & PP \\
\hline Lrer & -2.15 & 0.227 & -4.530 & 0.001 & -2.58 & 0.110 & -4.53 & 0.001 \\
Lnfa & -0.78 & 0.811 & -6.64 & 0.000 & -0.56 & 0.865 & -6.65 & 0.000 \\
Lexp & 0.330 & 0.967 & -6.09 & 0.000 & 0.38 & 0.979 & -6.07 & 0.000 \\
MS & -2.97 & 0.047 & - & - & - & - & - & - \\
IRD & -2.38 & 0.152 & -6.22 & 0.000 & -2.41 & 0.147 & -6.20 & 0.000 \\
\hline
\end{tabular}

Table 3. Trace and Max-Eigen tests

\begin{tabular}{ccccccccc}
\hline $\begin{array}{c}\text { Null } \\
\text { Hypothesis }\end{array}$ & $\begin{array}{c}\text { Alternative } \\
\text { Hypothesis }\end{array}$ & Optimal LL & $\begin{array}{c}\text { Trace } \\
\text { Statistic }\end{array}$ & $\begin{array}{c}5 \% \\
\text { Critical Value }\end{array}$ & Prob. & $\begin{array}{c}\text { Max-Eigen } \\
\text { Statistic }\end{array}$ & $\begin{array}{c}5 \% \\
\text { Critical Value }\end{array}$ & Prob. \\
\hline $\mathrm{r} \leq 0$ & $\mathrm{r}=1$ & 2 & 74.83 & 69.81 & 0.018 & 34.40 & 33.87 & 0.043 \\
$\mathrm{r} \leq 1$ & $\mathrm{r}=2$ & 2 & 40.43 & 47.85 & 0.207 & 21.24 & 27.58 & 0.261 \\
\hline
\end{tabular}

Note. The optimal lag length (LL) is determined by Akaike information criterion.

Table 4. The long run model of the equilibrium real exchange rate

\begin{tabular}{ccccc}
\hline Variable & Variable abbreviation & Coefficient & Std.Errors & t-ratio \\
\hline Net Foreign Assets & NFA & $-0.517 * * *$ & 0.223 & -2.31 \\
Government Expenditure & Exp & $2.83^{* * *}$ & 0.837 & 3.38 \\
Monetary Stance & MS & $-0.121^{* * *}$ & 0.034 & -3.56 \\
Interest Rate Differential & IRD & $-0.307 * * *$ & 0.046 & -6.72 \\
\hline $\mathrm{R}^{2}$ & & 0.400 & \\
Portmanteau Test (Prob.) & & 0.162 & \\
Residual Heteroskedasticity (Prob.) & & 0.521 & & \\
\hline
\end{tabular}

Note. Standard errors between parentheses. Tabulated t-test is between brackets. The residual diagnostic tests indicate that the model is lack of autocorrelation and heteroskedasticity problems. The null hypothesis of Autocorrelation and heteroskedasticity tests is that the errors are uncorrelated and homoskedastic. *** denotes significance at $1 \%$ level of confidence.

\subsection{Actual Real Exchange Rate, Equilibrium Real Exchange Rate and Misalignment}

Based on the normalized cointegrating estimates and following the permanent equilibrium approach, the unobserved equilibrium real exchange rate is obtained by the multiplication of the sustainable values of the macroeconomic fundamentals, computed using the Hodrick-Prescott filter, and the cointegrating coefficients. The misalignment is then calculated by subtracting the difference between the actual real exchange rate and the equilibrium real exchange rate. 
Figure 1 shows the actual real exchange rate, with the dotted line, and the equilibrium real exchange rate, with the continuous line. The actual real exchange rate is said to be overvalued if misalignment is negative.

The actual real exchange rate remained below the equilibrium real exchange rate from 1980 to 1986, and then it went slightly up during 1987 to 1989, the period of the Jordanian Dinar crisis (Note 6). However, the exchange rate remained depreciated three years prior to adopting the fixed exchange rate system to the US dollar in October 1995 until 2006. Between 2006 and 2008, the misalignment was negative as the real exchange rate fell below the equilibrium real exchange rate indicating a period of appreciation. In 2009, the real exchange rate depreciated slightly by around $0.3 \%$. However, interestingly, the misalignment faded out after 2011 .

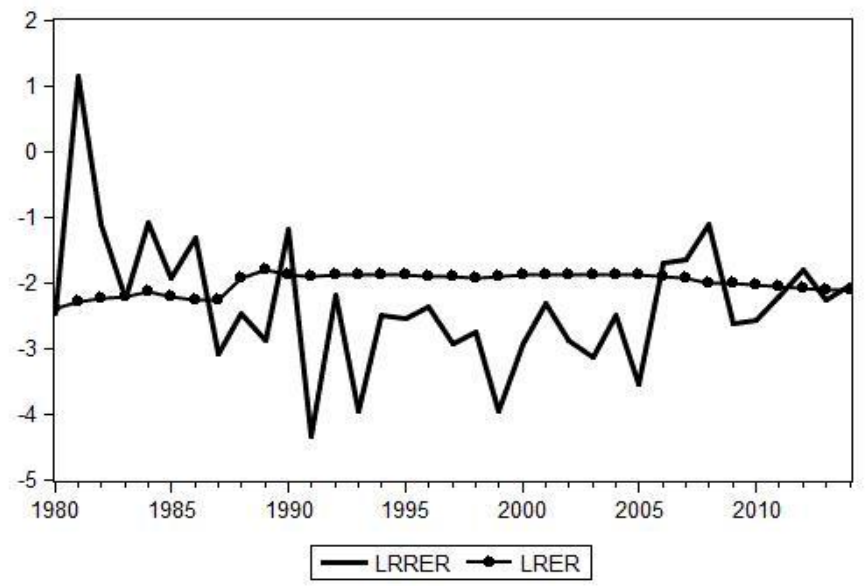

Figure 1. Actual Exchange Rate (LRER) and Equilibrium Real Exchange Rate (LRRER)

\subsection{Growth and Misalignment}

Many studies have attempted to study the impact of real exchange rate on the economic growth, see e.g. Razin and Collins (1997), Aguirreand Calderón (2005); Papanikos (2015) and Owoundi (2016). Nevertheless, due to limited number of observation at hand, and considering the robustness of the results, we add only investment to GDP ratio to the model relating economic growth to real exchange rate misalignment. The model can be presented as follows.

$$
\text { Growth }=\beta_{0}+\beta_{1} I N V+\beta_{2} M I S+\varepsilon_{t}
$$

Where Growth is GDP per capita income; INV is the ratio of investment to GDP and MIS is the deviation of real exchange rate (rer) from the equilibrium real exchange rate (ERER). Mathematically: $M I S=R E R-E R E R$.

Ensuring that the variables are stationary at level, we apply ordinary least square to estimate equation 8 . The results presented in Table 5 indicate that misalignment affects the growth per capita income negatively. A $1 \%$ increase in misalignment decreases the growth by roughly $9 \%$. Expectedly, investment is found to significantly increase growth. However, overvaluation and undervaluation of the exchange rate may not have the same impact on economic growth. That is, real exchange rate devaluation which comes through the prices channel might increase the growth if the Marshall-Lerner condition satisfies. Hence, a plausible asymmetric relationship between misalignment and growth needs further investigation once longer time series data become available.

Table 5. OLS estimation of the nexus between growth and misalignment

\begin{tabular}{ccccc}
\hline Variable & Variable abbreviation & Coefficient & Std.Errors & t-ratio \\
\hline Investment & INV & $0.147 * * *$ & 0.026 & 5.56 \\
Misalignment & MIS & $-9.34 * * *$ & 2.37 & -3.93 \\
$\mathrm{R}^{2}$ & & 0.45 & & \\
Breusch-Godfrey Serial Correlation LM Test (Statistic/Prob.) & & $1.09 / 0.345$ & & \\
Residual Heteroskedasticity (Statistic/Prob.) & & $-2.15 / 0.22$ & \\
\hline
\end{tabular}

Note. The null hypothesis of Autocorrelation and heteroskedasticity tests is that the errors are uncorrelated and homoskedastic. *** indicate significance at $1 \%$ level of confidence. 


\section{Conclusions}

The goal of this paper is to empirically analyze and estimate the deviation of the real exchange rate from its equilibrium path in Jordan to assess the impact of the fixed exchange rate system on exchange rate misalignment. Following the equilibrium real exchange rate approach, we develop an indicator for the real exchange rate misalignment in Jordan over the yearly span from 1980 to 2014.

Johansen technique is used to estimate the long-run relationship between the real exchange rate and a selected number of macroeconomic fundamentals that are supposed to capture the long-run influence of the behavior of the long-run real exchange rate.

One cointegrating relationship is found among the variables and the estimation results are consistent with the theoretical predications. Following the permanent equilibrium based approach we multiply the sustainable values of the economic fundamentals and the estimated coefficients from the cointegrated equation to compute the equilibrium real exchange rate. The estimated equilibrium exchange rate is used to calculate the misalignment of the real exchange rate. The misalignment results indicate that Jordan experienced episodes of undervaluation over a long period of exchange rate fixity, i.e. from 1995 to 2006, but the exchange rate misalignment receded after 2011. In this regard, the persistence of misalignment hided by the fixed exchange rate system may worsen the credit position of the economy. However, the problem of long-run real exchange rate in developing countries appears in a situation where the current account deficit is financed by the non-reserve financial account and the official reserve settlement balance or net capital inflows. Thus the fundamentals may not be strong at reflecting whether the long-run real exchange rate implies that the economy has reached its presumed international position.

We also attempt to model the nexus between the real exchange rate misalignment and economic growth. The misalignment affects the economic growth negatively. Given the limited number of observations at hand, it is suggested that further studies are needed to investigate the asymmetric effect of exchange rate on economic growth once longer time series data become available for Jordan. Indeed, in general, short time series do not enable considering many determinants namely variables or dummies accounting for political or economic disturbances that should be imposed in the analysis.

\section{References}

Aguirre, A., \& Calderón, C. (2005). Real exchange rate misalignments and economic performance. Documentos de Trabajo (Banco Central de Chile), (315), 1-49.

Aizenman, J., \& Lee, J. (2007). International reserves: Precautionary versus mercantilist views, theory and evidence. Open Economies Review, 18(2), 191-214. http://dx.doi.org/10.1007/s11079-007-9030-z

Baffes, J., Elbadawi, I. A., \& O'connell, S. A. (1997). Single-equation estimation of the equilibrium real exchange rate (No. 1800). World Bank, Development Research Group.

Bayoumi, T., \& Symansky, S. (1994). Robustness of equilibrium exchange rate calculations to alternative assumptions and methodologies. IMF Working Paper WP/94/17.

Clark, P. B., \& MacDonald, R. (1999). Exchange rates and economic fundamentals: A methodological comparison of BEERs and FEERs. In Equilibrium exchange rates (pp. 285-322). Springer Netherlands. https://doi.org/10.1007/978-94-011-4411-7_10

Coudert, V., \& Couharde, C. (2009). Currency misalignments and exchange rate regimes in emerging and developing countries. Review of International Economics, 17(1), 121-136. http://dx.doi.org/10.1111/j.1467-9396.2008.00782.x

Dickey, D. A., \& Fuller, W. A. (1979). Distribution of the estimators for autoregressive time series with a unit root. Journal of the American Statistical Association, 74(366a), 427-431. http://dx.doi.org/10.1080/01621459.1979.10482531

Dubas, J. M. (2009). The importance of the exchange rate regime in limiting misalignment. World Development, 37(10), 1612-1622. http://dx.doi.org/10.1016/j.worlddev.2009.02.003

Edwards, S. (1989). Exchange rate misalignment in developing countries. The World Bank Research Observer, 4(1), 3-21. https://doi.org/10.1093/wbro/4.1.3

Elhendawy, E. O. (2012). Real Exchange Rate Misalignment in Saudi Arabia. International Journal of Economics and Finance, 4(12), 98. https://doi.org/10.5539/ijef.v4n12p98

Frenkel, J. A., Razin, A., \& Yuen, C. W. (1996). Fiscal policies and growth in the world economy. MIT press. 
Hausmann, R., Pritchett, L., \& Rodrik, D. (2005). Growth accelerations. Journal of Economic Growth, 10(4), 303-329. http://dx.doi.org/ 10.1007/s10887-005-4712-0

Hinkle, L. E., \& Monteil, P. J. (1999). Exchange rate misalignment: Concepts and measurement for developing countries. Oxford University Press.

Hjalmarsson, E., \& Österholm, P. (2007). A residual-based cointegration test for near unit root variables. FRB International Finance Discussion Paper, (907). https://doi.org/10.2139/ssrn.1066746

Holtemöller, O., \& Mallick, S. (2008). Real Exchange Rate Misalignment and the Choice of Currency Regime. In 65th International Atlantic Economic Conference Home Page.

Johansen, S. (1988). Statistical analysis of cointegration vectors. Journal of Economic Dynamics and Control, 12(2), 231-254. http://dx.doi.org/10.1016/0165-1889(88)90041-3

Kiptoo, C. K. (2009). Empirical analysis of the real exchange rate misalignments: The case of selected COMESA countries. http://dx.doi.org/10.1.1.410.7564

Kubota, M. (2009). Real exchange rate misalignments: Theoretical modelling and empirical evidence. Discussion Papers in Economics. York: University of York.

Marston, R. C. (1988). Introduction to "Misalignment of Exchange Rates: Effects on Trade and Industry". In Misalignment of Exchange Rates: Effects on Trade and Industry (pp. 1-8). University of Chicago Press. https://doi.org/10.7208/chicago/9780226507255.001.0001

Nouira, R., \& Sekkat, K. (2015). What determines the extent of real exchange rate misalignment in developing countries? International Economics, 141, 135-151. http://dx.doi.org/10.1016/j.inteco.2015.02.001

Osterwald-Lenum, M. (1992). A note with quantiles of the asymptotic distribution of the maximum likelihood cointegration rank test statistics1. Oxford Bulletin of Economics and statistics, 54(3), 461-472. http://dx.doi.org/10.1111/j.1468-0084.1992.tb00013.x

Owoundi, F. (2016). Do exchange rate misalignments really affect economic growth? The case of Sub-Saharan African countries. International Economics, 145, 92-110. http://dx.doi.org/10.1016/j.inteco.2015.10.001

Papanikos, G. T. (2015). The real exchange rate of euro and Greek economic growth. The Journal of Economic Asymmetries, 12(2), 100-109. http://dx.doi.org/10.1016/j.jeca.2015.04.002

Perron, P. (1988). Trends and random walks in macroeconomic time series: Further evidence from a new approach. Journal of Economic Dynamics and Control, 12(2-3), 297-332. http://dx.doi.org/10.1016/0165-1889(88)90043-7

Petri, M. M., \& Saadi-Sedik, T. (2006). To Smooth or Not to Smooth: The Impact of Grants and Remittances on the Equilibrium Real Exchange Rate in Jordan (No. 6-257). International Monetary Fund. https://doi.org/10.5089/9781451865172.001

Razin, O., \& Collins, S. M. (1997). Real exchange rate misalignments and growth (No. w6174). National Bureau of Economic Research. https://doi.org/10.3386/w6174

Rodrik, D. (2008). The real exchange rate and economic growth. Brookings Papers on Economic Activity, (2), 365-412.

Rogoff, K. (1996). The purchasing power parity puzzle. Journal of Economic Literature, 34(2), 647-668.

Warrad, T. A. (n. d.). Real Exchange Rate Misalignment and Economic Performance: The Case of Jordan. The WTOChair program-Jordan. Retrieved from http://wtochair.ju.edu.jo/Documents/taleb-rermis\%20final1.pdf

\section{Notes}

Note 1. However, the choice of optimal exchange rate regime to limiting misalignment is controversial. Nouira and Sekkat (2015) find that intermediate regimes induce more misalignment volatility than float and fixed regimes, while they are most effective at preventing exchange rate misalignment according to Dubas (2009).

Note 2. For more detail on the exchange rate history in Jordan, the reader is refereed to Petri and Saadi-Sedik (2006).

Note 3. See also Bayoumi and Symansky (1994).

Note 4. We first projected the real interest rate differential, as suggested by the uncovered interest rate parity condition theory. However, the results are found to be better off with the projection of the nominal interest rate 
differential.

Note 5. Note that we cannot determine whether the expansion raises the demand for tradable or non-tradable goods and which of either effect dominates.

Note 6. For more details on the 1989 Dinar crisis see Petriand Saadi-Sedik (2006).

\section{Copyrights}

Copyright for this article is retained by the author(s), with first publication rights granted to the journal.

This is an open-access article distributed under the terms and conditions of the Creative Commons Attribution license (http://creativecommons.org/licenses/by/4.0/). 